DOI

\title{
ПОРІВНЯЛЬНА ДІЯ ГАЛОВОЇ КИСЛОТИ ТА КВЕРЦЕТИНУ НА ПОКАЗНИКИ ФУНКЦІОНАЛЬНОГО СТАНУ НИРОК ЩУРІВ ЗА УМОВ ЕКСПЕРИМЕНТАЛЬНОГО ДІАБЕТУ 2 типу
}

\author{
๑А. Л. Загайко, Г. Б. Кравченко \\ Національний фармацевтичний університет, Харків
}

\begin{abstract}
РЕЗЮМЕ. Науковці перебувають у постійному пошуку нових молекул, які можуть бути використані в якості біологічно активних функціональних інгредієнтів у боротьбі з діабетом та його ускладненнями. У цьому контексті флавоноїди $\epsilon$ групою молекул, інтерес до яких зростає. Метою дослідження було порівняльне вивчення ефекту біофлавоноїдів кверцетину та галової кислоти на функціональний стан нирок у щурів з експериментальним цукровим діабетом 2 типу. Лікування з використанням досліджених фенольних сполук значно зменшує ниркову дисфункцію. При цьому кверцетин проявив дещо вищу активність, що корелює з вищою антиоксидантною здатністю.

КЛЮчОВІ СлОВА: цукровий діабет 2 типу, діабетична нефропатія, галова кислота, кверцетин.
\end{abstract}

Вступ. Згідно з даними Всесвітньої організації охорони здоров'я (ВООЗ) кількість хворих на цукровий діабет 2 типу (ЦД 2) з 1980 до 2014 року виросла вдвічі та склала 422 мільйони чоловік, і ця тенденція зберігається [8]. Велику увагу також приділяють ускладненням діабету, тому що саме вони призводять до втрати зору, ниркової недостатності, ампутації кінцівок та інших ускладнень, які суттєво знижують якість життя та навіть призводять до летальних наслідків. Тому профілактика та лікування ускладнень ЦД 2 настільки ж важливі, як і лікування самої хвороби. Діабетична нефропатія, яка є наслідком ураження мікросудин та однією з головних причин термінальної стадії ниркової недостатності, реєструється як мінімум у 40 \% хворих на ЦД 2 [6]. Багато досліджень, як епідеміологічних, так і експериментальних, показали, що окиснювальний стрес $є$ основним патологічним механізмом розвитку діабетичної нефропатії $[2,14]$.

Науковці перебувають в постійному пошуку нових молекул для застосування в якості біологічно активних функціональних інгредієнтів у боротьбі з діабетом та його ускладненнями. У цьому контексті флавоноїди викликають зростаючий інтерес $[1,7]$. Для нашого дослідження ми обрали кверцетин (3,3 , 4,5,7-пентагідроксіфлавон) та галову кислоту (3,4,5-тріоксибензойна кислота), які наявні у органах та плодах багатьох видів рослин, зокрема у чаї, винограді, яблуках, чорниці, та $є$ потужними антиоксидантами (мають цілий спектр фармакологічної активності) [10, 11, 15].

Метою дослідження було порівняльне вивчення ефекту біофлаваноїдів кверцетину та галової кислоти на функціональний стан нирок у щурів з екпериментальним ЦД 2.

Матеріал і методи дослідження. У експерименті використовували безпородних щурівсамців віком 6 місяців, які були поділені на 4 гру- пи: 1) група контролю - інтактні тварини; 2) група контрольної патології, тварини, яким після 90-добового утримання на комбінованій дієті 3 надмірним вмістом насичених жирів (білки 20 \%, жири - 60 \%, вуглеводи - 20 \% від загальних калорій в раціоні та надмірного споживання вуглеводів (вільний доступ до розчину фруктози в концентрації 200 г/л)) внутрішньочеревно вводили стрептозотоцин (30 мг/кг, на цитратному буфері) [18]; 3) тварини, яким на фоні моделювання ЦД 2 типу (див. група 2) перорально щоденно, починаючи з 95 доби експерименту, вводили суспензію кверцетину (ПАТ НВЦ «Борщагівський хіміко-фармацевтичний завод») у дозі 30 мг діючої речовини / кг маси тіла протягом 2 тижнів; 4) тварини, яким на фоні моделювання ЦД 2 типу (див. група 2) перорально вводили галову кислоту («Sigma-Aldrich») у дозі 30 мг діючої речовини / кг маси тіла протягом 2 тижнів. Після закінчення експерименту в сироватці крові визначали вміст сечовини, креатиніну, калію, натрію, активність $\gamma$-глутамілтранспептидази (ГГТП) уніфікованими методами (ТОВ НВП «Філісіт-Діагностика», Україна) та трансамінідази (гліцинамідінотрансферази) [17]. Для збору сечі щурів в останню добу експерименту розміщували в метаболічних клітках. У сечі визначали білок, креатинін, сечовину уніфікованими методами (ТОВ НВП «Філісіт-Діагностика», Україна). При проведенні експериментів дотримувалися «Загальних етичних принципів експериментів на тваринах (Україна, 2001), гармонізованих Європейською конвенцією про захист хребетних тварин, які використовуються для наукових цілей (Страсбург, 1985). Статистичну обробку отриманих даних проводили з використанням пакета програм Statistic 6.0 (StatSoft Inc., USA).

Результати й обговорення. Паралельно 3 результатами, які обговорюються в даній статті, 
Огляди літератури, оригінальні дослідження, погляд на проблему

в експериментальних дослідженнях було підтверджено розвиток ЦД 2 у щурів за умов нашого експерименту.

Протеїнурія $є$ одним з головних показників, які підтверджують розвиток діабетичної нефропатії [12]. У сечі тварин групи з модельною патологією було зафіксоване підвищення добового вмісту білка, водночас показники добової екскреції креатиніну та сечовини були значно нижчими від нормальних, що вказує на порушення під час фільтрації. Введення досліджуваних сполук зни- жувало вміст білка в сечі: введення кверцетину більш ніж у два рази. Також підвищився добовий вміст сечовини та креатиніну, що свідчить про нормалізацію функції нирок (табл. 1).

Поряд з цим також відбувалися зміни досліджуваних показників у сироватці крові - підвищувався вміст сечовини в 1,6 раза, креатиніну в 2,2 раза та знижувався загальний білок. Введення як кверцетину, так і галової кислоти значно послаблювало ознаки ниркової дисфункції у щурів, хворих на ЦД 2 (табл. 2).

Таблиця 1. Показники функціонального стану нирок у сечі щурів з експериментальним ЦД 2 та при введенні кверцетину і галової кислоти $(\mathrm{M} \pm \mathrm{m}, \mathrm{n}=6)$

\begin{tabular}{|l|c|c|c|c|}
\hline \multirow{2}{*}{\multicolumn{1}{|c|}{ Показники }} & \multicolumn{3}{|c|}{ Групи тварин } \\
\cline { 2 - 5 } & інтактні тварини & $\begin{array}{c}\text { контрольна } \\
\text { патологія }\end{array}$ & кверцетин & галова кислота \\
\hline Сечовина, ммоль/л & $169,13 \pm 8,94$ & $121,31 \pm 4,82^{1}$ & $170,24 \pm 2,12^{2}$ & $154,14 \pm 2,12^{12}$ \\
\hline Креатинін, млмоль/л & $18,41 \pm 1,01$ & $5,45 \pm 0,61^{1}$ & $16,54 \pm 0,87^{2}$ & $15,92 \pm 0,97^{12}$ \\
\hline Білок, мг/доба & $8,21 \pm 0,92$ & $22,91 \pm 1,53^{1}$ & $9,59 \pm 0,872$ & $13,64 \pm 0,89^{12}$ \\
\hline
\end{tabular}

Примітка: 1 - p $\leq 0,05$ щодо інтактних тварин; 2 - p $\leq 0,05$ щодо контрольної патології.

Таблиця 2. Показники функціонального стану нирок у сироватці крові щурів з експериментальним ЦД 2 та при введенні кверцетину і галової кислоти $(\mathrm{M} \pm \mathrm{m}, \mathrm{n}=6)$

\begin{tabular}{|l|c|c|c|c|}
\hline \multirow{2}{*}{\multicolumn{1}{|c|}{ Показники }} & \multicolumn{3}{c|}{ Групи тварин } \\
\cline { 2 - 5 } & $\begin{array}{c}\text { інтактні } \\
\text { тварини }\end{array}$ & $\begin{array}{c}\text { контрольна } \\
\text { патологія }\end{array}$ & кверцетин & галова кислота \\
\hline Загальний білок, г/л & $56,51 \pm 2,98$ & $39,62 \pm 4,56^{1}$ & $52,36 \pm 7,32^{12}$ & $45,34 \pm 6,84^{12}$ \\
\hline Сечовина, ммоль/л & $6,52 \pm 0,54$ & $10,74 \pm 0,76^{1}$ & $7,78 \pm 0,81^{12}$ & $8,32 \pm 0,63^{12}$ \\
\hline Креатинін, мкмоль/л & $112,36 \pm 10,23$ & $242,58 \pm 13,45^{1}$ & $163,45 \pm 12,82^{12}$ & $168,87 \pm 12,45^{12}$ \\
\hline Калій, ммоль/л & $5,58 \pm 0,34$ & $7,46 \pm 0,38^{1}$ & $5,62 \pm 0,43^{2}$ & $5,55 \pm 0,64^{2}$ \\
\hline Натрій, ммоль/л & $132,45 \pm$ & $98,23 \pm 9,82^{1}$ & $127,29 \pm 19,17^{2}$ & $121,61 \pm 13,8^{2}$ \\
\hline Активність ГГТП, мкмоль/год×мл & $1,51 \pm 0,021$ & $1,74 \pm 0,034^{1}$ & $1,60 \pm 0,025^{12}$ & $1,65 \pm 0,032^{12}$ \\
\hline $\begin{array}{l}\text { Активність трансамінідази, } \\
\text { ммоль/годхл }\end{array}$ & - & $1,02 \pm 0,032^{1}$ & $0,16 \pm 0,042^{12}$ & $0,21 \pm 0,041^{12}$ \\
\hline
\end{tabular}

Примітка: 1 - p $\leq 0,05$ щодо інтактних тварин; 2 - p $\leq 0,05$ щодо контрольної патології.

Нирки є органом, який безпосередньо бере участь в регуляції вмісту електролітів сироватки крові. При дослідженні концентрації натрію було зафіксоване зниження його концентрації на 29 \% у тварин 3 контрольною патологією, тоді як концентрація калію підвищувалася на 33 \%, що вказує на розвиток патології нирок, однак застосування як кверцетину, так і галової кислоти призводило до нормалізації цих показників (табл. 2)

У хворих на ЦД 2 при порушенні мікроциркуляції в нирках уражаються проксимальні канальці нирок $[4,6]$, тому нам було цікаво дослідити активність в сироватці крові таких ферментів, як ГГТП та трансамінідаза. Трансамінідаза досить активна у нирках, оскільки нирки - це орган, у якому синтезується креатин, тому цей фермент можна вважати органоспецифічним [3, 6]. Трансамінідаза переважно локалізована у проксимальних канальцях нирок та саме їхнє ушкодження призводить до зростання активності цього ферменту в сироватці крові. У здорових тварин активність трансамінідази не виявляється, однак наслідки ускладнень ЦД 2 призвели до значного зростання її активності у сироватці крові, яка визначалася і після лікування (табл. 2). На сьогодні відомо, що при діабеті відбувається зростання активності ГГТП у крові хворих, проте, враховуючи, що ГГТП зокрема локалізована в мембранах проксимальних канальців нирок, ми дослідили її активність у крові $[5,9,13,16]$. У нашому експерименті у щурів, хворих на діабет, її активність очікувано зростала, а при лікуванні дещо знижувалася, хоча і не досягала рівня здорових тварин. 
Висновки. Лікування з використанням досліджених фенольних сполук значно послаблює ниркову дисфункцію. При цьому кверцетин проявив дещо вищу активність, що корелює з вищою антиоксидантною здатністю. Ці результати підтверджують роль окиснювального стресу в розвитку діабетичної нефропатії та вказують на роль

\section{ЛITEPATУРA}

1. Beneficial Effects of Quercetin on Obesity and Diabetes / L. Aguirre, N. Arias, M. T. Macarulla [et al.] // The Open Nutraceuticals Journal. - 2011. - № 4. - P. 189-198.

2. Quercetin Ameliorates Diabetic Nephropathy in Rats via Modulation of Renal NA+, K+-ATP-ase Expression and Oxidative Stress / S. O. Bashir, M. D. Morsy, H. F. Sakr [et al.] // American Journal of Pharmacology and Toxicology. - 2014. - № 9 (1). - P. 84-95.

3. Bazzano T. Renal biomarkers of male and female Wistar rats (Rattus norvegicus) undergoing renal ischemia and reperfusion / T. Bazzano, T. I. Restel, L. C. Porfirio [et al.] // Acta Cirúrgica Brasileira - 2015. - Vol. 30 (4) P. 277-288.

4. Standardization of renal function evaluation in Wistar rats (Rattus norvegicus) from the Federal University of Juiz de Fora's colony / B. B. A. de Castro, F. A. B. Colugnati, M. A. Cenedeze [et al.] // The Jornal Brasileiro de Nefrologia. - 2014. - № 36 (2). - P. 139-149.

5. Cho H. C. The Association between Serum GGT Concentration and Diabetic Peripheral Polyneuropathy in Type 2 Diabetic Patients // Korean Diabetes Journal. 2010. - № 34. - P. 111-118.

6. Diseases of Renal Parenchyma / edited by M. Sahay. - InTech, 2012. - 304 p.

7. El-Gohary O. A. Effect of Exercise and Quercetin on Obesity Induced Metabolic and Renal Impairments in Albino Rats / O. A. El-Gohary, N. I. Hussien // Journal of Physiology and Pharmacology Advances. - 2015. - № 5 (3). P. 589-602.

8. Global report on diabetes. World Health Organization World Health Organization 2016. WHO Library Cataloguing-in-Publication. Data available on the WHO website: http://www.who.int.

9. Relationship between gamma-glutamyl transferase and glucose intolerance in first degree relatives of type 2 diabetics patients / S. Haghighi, M. Amini, Z. Pournaghshband [et al.] // International Journal of Research in Medical Sciences. - 2011. - № 16 (2). - P. 123-129. антиоксидантного механізму в нефропротекторній дії кверцетину.

Перспективи подальших досліджень. Ми вважаємо доцільним вивчити вплив фенольних сполук на інші ланки метаболізму за умов ЦД 2, зокрема на систему оксиду нітрогену.

10. Preventive Effects of Flavonoids on Alloxan-Induced Diabetes Mellitus in Rats / A. Lukacinova, J. Mojzis, R. Benacka [et al.] // Acta Veterinaria Brunensis. - 2008. № 77. - P. 175-182.

11. Quercetin Protects against Diabetes-Induced Exaggerated Vasoconstriction in Rats: Effect on Low Grade Inflammation / M. F. Mahmoud, N. A. Hassan, H. M. El Bassossy [et al.] // J. Res Med Sci. - 2011. - № 16(2). - P. 123-129.

12. Urinary Protein Profiles in a Rat Model for Diabetic Complications / D. M. Schlatzer, J.-E. Dazard, M. Dharsee [et al.] // Molecular \& Cellular Proteomics. - 2009. - № 8 (9). P. 2145-2158.

13. Sun K. Serum Gamma - Glutamyltransferase Is Associated with Albuminuria: A Population-Based Study / K. Sun, L. Feng, L. Diaozhu // PLoS One. - 2014. - № 9 (12). DOI:10.1371/journal.pone.0114970.

14. Tervaert T. W. C. Pathologic Classification of Diabetic Nephropathy / T. W. C. Tervaert, A. L. Mooyaart, K. Amann // Journal of American Society of Nephrology. 2010. - № 21. - P. 556-563.

15. Umadevi S. Regulatory mechanism of gallic acid against advanced glycation end products induced cardiac remodeling in experimental rats / S. Umadevi, V. Gopi, V. Elangovan [et al.] // Chemico-Biological Interactions. 2014. - № 208. - P. 28-36.

16. Gamma-Glutamyl Transferase is Related to Microalbuminuria in Diabetic Patients / A. Ünal, í. Çerçi, E. Doğan [et al.] //Türk Nefroloji Diyaliz ve Transplantasyon. - 2014. № 23 (3). - P. 217-222.

17. Клінічна біохімія : навч. посіб. / за ред. О. П. Тимошенко. - К. : Вид-во «Професіонал», 2005. - 288 с.

18. Пат. 38466 Україна, МПК G09B 23/28 (2008.01). Спосіб моделювання цукрового діабету 2 типу у щурів / О. І. Гладких, В. В. Полторак, Н. С. Красова та ін.; заявник і патентовласник ДУ «Інститут проблем ендокринної патології ім. В. Я. Данилевського» АМН України. - № U 200810259; заявл. 11.08.2008 р. Опубл. 12.01.2009 р. - Бюл. № 1. - 4 с.

\title{
COMPARATIVE EFFECT OF GALLIC ACID AND QUERCETIN ON RENAL FUNCTION INDICATORS IN RATS UNDER THE EXPERIMENTAL DIABETES MELLITUS TYPE 2
}

\author{
@A. L. Zahayko, H. B. Kravchenko
}

\section{National University of Pharmacy}

SUMMARY. Scientists are constantly searching for the new molecules that can be used as bioactive functional ingredients to treat diabetes mellitus and its complications. In this context, flavonoids are the group of molecules under increasing interest. The aim of the study was to compare the effect of bioflavonoids quercetin and gallic acid on renal function in rats under experimental type 2 diabetes. Treatment with studied phenolic compounds significantly reduced renal dysfunction. However, quercetin showed higher activity that correlates with its higher antioxidant capacity.

KEY WORDS: diabetes mellitus type 2, diabetic nephropathy, gallic acid, quercetin. 